\title{
Why Are B Ions Stable Species in Peptide Spectra?
}

\author{
Talat Yalcin, Charlotte Khouw, Imre G. Csizmadia, Michael R. Peterson, \\ and Alex G. Harrison \\ Department of Chemistry, University of Toronto, Toronto, Ontario M5S 1A1, Canada
}

Protonated amino acids and derivatives $\left.\mathrm{RCH}\left(\mathrm{NH}_{2}\right) \mathrm{Cl}=\mathrm{O}\right) \mathrm{X} \cdot \mathrm{H}^{+}\left(\mathrm{X}=\mathrm{OH}, \mathrm{NH}_{2}, \mathrm{OCH}_{3}\right)$ do not form stable acylium ions on loss of $\mathrm{HX}$, but rather the acylium ion eliminates $\mathrm{CO}$ to form the immonium ion $\mathrm{RCH}=\mathrm{NH}_{2}^{+}$. By contrast, protonated dipeptide derivatives $\mathrm{H}_{2} \mathrm{NCH}(\mathrm{R}) \mathrm{C}(=\mathrm{O}) \mathrm{NHCH}\left(\mathrm{R}^{\prime}\right) \mathrm{C}(=\mathrm{O}) \mathrm{X} \cdot \mathrm{H}^{+}\left[\mathrm{X}=\mathrm{OH}, \mathrm{OCH}_{3}, \mathrm{NH}_{2}, \mathrm{NHCH}\left(\mathrm{R}^{\prime \prime}\right) \mathrm{COOH}\right]$ form stable $B_{2}$ ions by elimination of $\mathrm{HX}$. These $B_{2}$ ions fragment on the metastable ion time scale by elimination of $\mathrm{CO}$ with substantial kinetic energy release $\left(T_{1 / 2}=0.3-0.5 \mathrm{eV}\right)$. Similarly, protonated $\mathrm{N}$-acetyl amino acid derivatives $\mathrm{CH}_{3} \mathrm{C}(=\mathrm{O}) \mathrm{NHCH}\left(\mathrm{R}^{\prime}\right) \mathrm{C}(=\mathrm{O}) \mathrm{X} \cdot \mathrm{H}^{+}$ $\left[X=\mathrm{OH}, \mathrm{OCH}_{3}, \mathrm{NH}_{2}, \mathrm{NHCH}\left(\mathrm{R}^{\prime \prime}\right) \mathrm{COOH}\right]$ form stable $\mathrm{B}$ ions by loss of $\mathrm{HX}$. These $\mathrm{B}$ ions also fragment unimolecularly by loss of $\mathrm{CO}$ with $T_{1 / 2}$ values of $\sim 0.5 \mathrm{eV}$. These large kinetic energy releases indicate that a stable configuration of the $B$ ions fragments by way of activation to a reacting configuration that is higher in energy than the products, and some of the fragmentation exothermicity of the final step is partitioned into kinetic energy of the separating fragments. We conclude that the stable configuration is a protonated oxazolone, which is formed by interaction of the developing charge (as HX is lost) with the $\mathrm{N}$-terminus carbonyl group and that the reacting configuration is the acyclic acylium ion. This conclusion is supported by the similar fragmentation behavior of protonated 2-phenyl-5-oxazolone and the $\mathrm{B}$ ion derived by loss of $\mathrm{H}-\mathrm{Gly}-\mathrm{OH}$ from protonated $\mathrm{C}_{6} \mathrm{H}_{5} \mathrm{C}(=\mathrm{O})-\mathrm{Gly}-\mathrm{Gly}-\mathrm{OH}$. In addition, ab initio calculations on the simplest $\mathrm{B}$ ion, nominally $\mathrm{HC}(=\mathrm{O}) \mathrm{NHCH}_{2} \mathrm{CO}^{+}$, show that the lowest energy structure is the protonated oxazolone. The acyclic acylium isomer is $1.49 \mathrm{eV}$ higher in energy than the protonated oxazolone and $0.88 \mathrm{eV}$ higher in energy than the fragmentation products, $\mathrm{HC}(=\mathrm{O}) \mathrm{N}^{+} \mathrm{H}=\mathrm{CH}_{2}+\mathrm{CO}$, which is consistent with the kinetic energy releases measured. (J Am Soc Mass Spectrom 1995, 6, 1165-1174)

$\mathrm{P}$ rotonated carboxylic acids fragment to a considerable extent by elimination of $\mathrm{H}_{2} \mathrm{O}$ to form stable acylium ions [1-4]. In the same vein, protonation of the methyl esters of carboxylic acids leads to substantial elimination of $\mathrm{CH}_{3} \mathrm{OH}$ that again forms stable acylium ions $[1,4-6]$. By contrast, protonated $\alpha$-amino acids, whether they are formed by chemical ionization (CI) [7-9], by fast-atom bombardment (FAB) $[10]$, or by plasma desorption $[9,11]$, do not form stable acylium ions by elimination of $\mathrm{H}_{2} \mathrm{O}$. Rather the highest mass fragment observed is the immonium ion $\mathrm{RCH}=\mathrm{NH}_{2}^{+}$that results from elimination of $\left(\mathrm{H}_{2}, \mathrm{C}\right.$, $\mathrm{O}_{2}$ ) from the $\mathrm{MH}^{+}$ion $\mathrm{RCH}\left(\mathrm{NH}_{2}\right) \mathrm{COOH} \cdot \mathrm{H}^{+}$. Similarly, protonated $\alpha$-amino acid methyl esters and amides do not appear to form stable acylium ions upon fragmentation, but once again immonium ions are observed as the highest mass fragment ions [9].

The failure to observe acylium ions in the $\mathrm{CI}$ mass spectra of $\alpha$-amino acids was rationalized qualitatively by Tsang and Harrison [8], who concluded that, although the acylium ion was formed as a transient

Address reprint requests to Alex G. Harrison, Department of Chemistry, University of Toronto, Toronto, Ontario M5S 1A1, Canada. species, the fragmentation reaction

$$
\mathrm{RCH}\left(\mathrm{NH}_{2}\right) \mathrm{CO}^{+} \rightarrow \mathrm{RCH}=\mathrm{NH}_{2}^{+}+\mathrm{CO}
$$

was exothermic due to the stability of the immonium ions formed. A recent detailed study by Hoppilliard and co-workers [9] of the fragmentation of protonated leucine concluded that fragmentation of the protonated species occurred by the pathway outlined in Scheme I $(\mathrm{R}=i-\mathrm{Bu})^{*}$. Thermochemical estimates of the heats of formation of $b$ and $c$ showed that they were higher in energy than the protonated species a or the final products $\mathrm{RCH}=\mathrm{NH}_{2}^{+}+\mathrm{CO}$. Experimentally, the fragmentation reaction $(\mathrm{R}=i-\mathrm{Bu})$

$\mathrm{RCH}\left(\mathrm{NH}_{2}\right) \mathrm{COOH} \cdot \mathrm{H}^{+} \rightarrow \mathrm{RCH}=\mathrm{NH}_{2}^{+}+\mathrm{CO}+\mathrm{H}_{2} \mathrm{O}$

\footnotetext{
*The loss of $\mathrm{H}_{2} \mathrm{O}$ is proposed to originate from a hydroxyl-protonated species formed by proton migration from the $\mathrm{N}$-protonated species. This differs from the $\mathrm{H}_{2} \mathrm{O}$-loss reaction in simple protonated carboxylic acids where protonation is believed to occur on the carbonyl oxygen [12] and $\mathrm{H}_{2} \mathrm{O}$ loss occurs by way of a 1,3- $\mathrm{H}$ shift that is symmetry forbidden and has a large energy barrier [3]. Experimentally, it was observed (Yalcin, T.; Dookeran, N. N.; Harrison, A. G., unpublished results) that there is complete randomization of all labile hydrogens in protonated amino acids prior to fragmentation.
} 


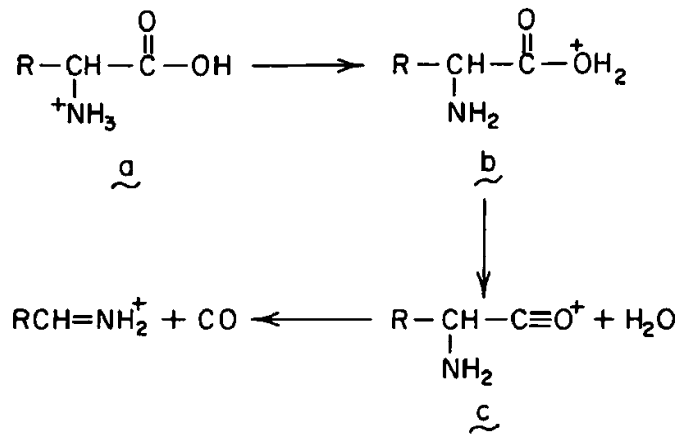

Scheme I

was found to occur on the metastable ion time scale to give a flat-topped metastable ion peak with a substantial release of kinetic energy $\left(T_{1 / 2}=0.39 \mathrm{eV}\right)$. This result is consistent with the intermediates $b$ and $c$ in the fragmentation sequence being higher in energy than the final products $[13,14]$.

In contrast to the simple amino acids and derivatives, the mass spectra of protonated peptides [both the FAB mass spectra and the collision-induced dissociation (CID) mass spectra] frequently show abundant formation of B-type ions [15-20] (Scheme II), which usually have been assumed to be acylium ions. Indeed, the $B_{n}$ series of ions often provides substantial sequence information for the peptide. The question arises as to why these B ions, which are nominally acylium ions, are stable when the acylium ions formed from amino acids are unstable.* The present work explores this question experimentally through CID and metastable ion studies, which include kinetic energy release measurements, with particular emphasis on $B_{2}$ ions. In addition, $a b$ initio calculations have been carried out to probe the potential energy surface for fragmentation of B-type ions.

\footnotetext{
"Stable" and "unstable" are to some extent ambiguous words. In the present context we imply only that $B_{n}(n \geq 2)$ ions exist in a potential well sufficiently deep that they survive long enough to be observed experimentally. By contrast, the $B_{1}$ ions derived from amino acids and derivatives do not appear to reside in a potential well and, therefore, are not observed. On a more quantitative scale, it appears that $B$ ions are less stable toward further fragmentation than their $Y$ counterparts [21].
}
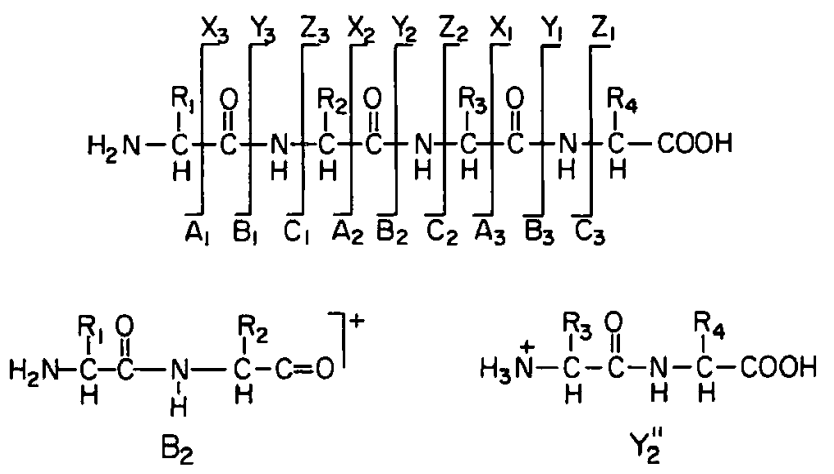

Scheme II

\section{Experimental}

All experiments were carried out with a VG Analytical (Manchester, UK) ZAB-2FQ mass spectrometer, which has been described in detail previously [22]. Briefly, the instrument is a reversed-geometry (BE) doublefocusing mass spectrometer with a third stage that consists of a deceleration lens system, a rf-only quadrupole collision cell, and a quadrupole mass analyzer. The ions studied were produced by fast-atom bombardment (FAB) by using an $\mathrm{Ar}$ atom beam of 7-8-keV energy with the appropriate sample dissolved in a matrix that consisted of thioglycerol-2,2'-dithiodiethanol $(1: 1)$ saturated with oxalic acid. The ion source was operated at room temperature.

To obtain relative intensities of fragment ions formed on the metastable ion time scale, the precursor ion of interest was mass-selected by the BE doublefocusing mass spectrometer at 6-keV ion energy, decelerated to $20-40-\mathrm{eV}$ energy, and introduced into the rf-only quadrupole cell in the absence of collision gas (base pressure $<10^{-8}$ torr). The products of unimolecular fragmentation in the quadrupole cell were measured by scanning the final quadrupole mass analyzer. Low energy collision-induced dissociation (CID) studies were carried out in the same fashion, but with the addition of $\mathrm{N}_{2}$ at an indicated pressure of 2-3 $\times$ $10^{-7}$ torr to the quadrupole collision cell. These pressures corresponded to $20-30 \%$ attenuation of the precursor ion intensity. In the CID experiments the incident ion energy was typically varied from 2 to $50 \mathrm{eV}$ (laboratory scale).

Kinetic energy releases associated with the unimolecular fragmentation reactions were determined by the mass-analyzed ion kinetic energy spectrometry (MIKES) technique [13]. In this technique the ion of interest was mass-selected by the magnetic sector at 6-keV kinetic energy and the products of unimolecular fragmentation in the drift region between the magnetic and electric sectors were identified in accordance with their kinetic energy by scanning the electric sector. The kinetic energy releases were determined, under conditions of good energy resolution, from the peak widths at half-height after correction for the inherent energy spread of the ion beam in accordance with the relation [14]

$$
W_{\text {corr }}=\left(W_{\text {met }}^{2}-W_{\text {mb }}^{2}\right)^{1 / 2}
$$

where $W_{\text {met }}$ is the measured width of the metastable ion and $W_{\mathrm{mb}}$ is the width of the parent ion main beam. The corrected half=widths were converted to $T_{1 / 2}$ values by using the equation developed [13] for electric sector scans. It should be noted that the time scale for unimolecular (metastable ion) fragmentation in the drift region before the electric sector (MIKES technique) is quite different from the time scale for unimolecular fragmentation in the rf-only quadrupole cell. For the former the time is $10-20 \mu$ s after ion formation 
in the source, whereas the time scale pertinent to the quadrupole cell is on the order of hundreds of microseconds. The same unimolecular fragmentation reactions were observed for fragmentation that occurs in both regions. Kinetic energy releases were, of necessity, measured for fragmentation reactions that occurred before the electric sector. Metastable ion spectra reproduced in the following text were recorded for fragmentation reactions that occurred in the quadrupole cell.

The compounds used were obtained from Aldrich Chemical Co. (Milwaukee, WI), Sigma Chemical Co. (St. Louis, MO), or Bachem Bioscience; Inc. (King of Prussia, PA). In a number of cases the $N$-acetyl derivatives of amino acids and peptides were prepared by reaction of the appropriate precursor that contained the free amino end with acetic anhydride in $t$-butanol. A portion of this reaction mixture was then added to the matrix used for FAB. The reference compound 2-phenyl-5-oxazolone was prepared by the reaction of hippuric acid with dicyclohexylcarbodiimide [23].

\section{Results and Discussion}

In our initial studies we examined the metastable ion fragmentation of a number of simple protonated amino acids and their amides and methyl esters. In all cases metastable peaks were observed for the nominal fragmentation reaction

$$
\begin{aligned}
& \mathrm{RCH}\left(\mathrm{NH}_{2}\right) \mathrm{C}(=\mathrm{O}) \mathrm{X} \cdot \mathrm{H}^{+} \\
& \rightarrow \mathrm{RCH}=\mathrm{NH}_{2}^{+}+\mathrm{CO}+\mathrm{HX}
\end{aligned}
$$

where $\mathrm{X}=\mathrm{OH}, \mathrm{NH}_{2}, \mathrm{CH}_{3} \mathrm{O}$. In no cases were metastable peaks observed that corresponded to elimination of $\mathrm{HX}$ alone. As the data in Table 1 indicate, reaction 4 yields flat-topped metastable ion peaks in all cases with $T_{1 / 2}$ values of $0.36-0.39 \mathrm{eV}$ for protonated amino acids, $0.30-0.37 \mathrm{eV}$ for the protonated amides, and $0.22-0.26 \mathrm{eV}$ for the protonated methyl esters. Our $T_{1 / 2}$ of $0.38 \mathrm{eV}$ for fragmentation of protonated leucine is in excellent agreement with the value of $0.39 \mathrm{eV}$

Table 1. Kinetic energy releases in fragmentation

\begin{tabular}{|c|c|c|}
\hline $\mathrm{M}$ of $\mathrm{MH}^{+}$ & Neutrals lost & $T_{1 / 2}(\mathrm{eV})$ \\
\hline $\mathrm{H}$-Leu-OH & $\mathrm{CO}+\mathrm{H}_{2} \mathrm{O}$ & 0.38 \\
\hline $\mathrm{H}$-Pro-OH & $\mathrm{CO}+\mathrm{H}_{2} \mathrm{O}$ & 0.39 \\
\hline $\mathrm{H}$-Phe-OH & $\mathrm{CO}+\mathrm{H}_{2} \mathrm{O}$ & 0.36 \\
\hline $\mathrm{H}$-Leu- $\mathrm{NH}_{2}$ & $\mathrm{CO}+\mathrm{NH}_{3}$ & 0.30 \\
\hline $\mathrm{H}$-Pro-NH $\mathrm{N}_{2}$ & $\mathrm{CO}+\mathrm{NH}_{3}$ & 0.37 \\
\hline H-Phe-NH ${ }_{2}$ & $\mathrm{CO}+\mathrm{NH}_{3}$ & 0.30 \\
\hline $\mathrm{H}-\mathrm{Hle}-\mathrm{NH}_{2}$ & $\mathrm{CO}+\mathrm{NH}_{3}$ & 0.36 \\
\hline $\mathrm{H}$-Leu-OCH & $\mathrm{CO}+\mathrm{CH}_{3} \mathrm{OH}$ & 0.24 \\
\hline $\mathrm{H}$-Pro- $\mathrm{OCH}_{3}$ & $\mathrm{CO}+\mathrm{CH}_{3} \mathrm{OH}$ & 0.24 \\
\hline $\mathrm{H}-\mathrm{Phe}-\mathrm{OCH}_{3}$ & $\mathrm{CO}+\mathrm{CH}_{3} \mathrm{OH}$ & 0.22 \\
\hline $\mathrm{H}$-lle- $\mathrm{OCH}_{3}$ & $\mathrm{CO}+\mathrm{CH}_{3} \mathrm{OH}$ & 0.26 \\
\hline
\end{tabular}
of protonated amino acids and derivatives reported earlier [9]. It is clear that protonated amino acid amides and methyl esters fragment by a pathway similar to that postulated for the amino acids themselves and outlined in Scheme I, and that the acylium ion initially formed fragments exothermically by elimination of $\mathrm{CO}$.

The fragmentation of protonated peptides is quite different in that B ions, which are conventionally assigned an acylium structure, are observed as stable species. This is illustrated by the example of two simple tripeptides: H-Gly-Leu-Gly-OH and H-LeuGly-Gly-OH. The FAB mass spectra of these two tripeptides show (Table 2) $\mathrm{MH}^{+}$as the base peak and appreciable intensities for the $B_{2}$ ion that arise by elimination of neutral glycine from $\mathrm{MH}^{+}$. Figures 1 and 2 illustrate the low energy CID of these two protonated tripeptides, where the results are presented in the form of breakdown graphs that express the percent fragment ion abundances as a function of the center-of-mass collision energy. In both cases the dominant fragmentation route of $\mathrm{MH}^{+}$involves loss of neutral glycine to form a stable $B_{2}$ ion of $m / z 171$. The low intensity $m / z 86$ ion observed in Figure 1 represents the immonium ion derived from leucine and may arise by further fragmentation of the $A_{2}$ ion, $m / z 143$.

On the metastable ion time scale fragmentation of protonated tripeptides occurs, at least in part, by elimination of the C-terminus amino acid to give a stable $B_{2}$ ion. Several examples are given in Table 3 . In all cases the metastable peak is Gaussian in shape with kinetic energy releases $\left(T_{1 / 2}\right)$ in the range $0.02-0.03 \mathrm{eV}$. In addition, protonated dipeptides and derivatives such as the amides and methyl esters show fragmentation on the metastable ion time scale to give stable $B_{2}$ ions, reaction 5 .

$$
\begin{aligned}
& \mathrm{RCH}\left(\mathrm{NH}_{2}\right) \mathrm{C}(=\mathrm{O}) \mathrm{NHCH}\left(\mathrm{R}^{\prime}\right) \mathrm{C}(=\mathrm{O}) \mathrm{X} \cdot \mathrm{H}^{+} \\
& \rightarrow \mathrm{B}_{2}^{+}+\mathrm{HX}
\end{aligned}
$$

As illustrated by the data in Table 3, these fragmentation reactions, which involve elimination of $\mathrm{H}_{2} \mathrm{O}, \mathrm{NH}_{3}$, or $\mathrm{CH}_{3} \mathrm{OH}$ from the $\mathrm{MH}^{+}$ion, show Gaussian shape metastable peaks with kinetic energy releases $\left(T_{1 / 2}\right)$ in the range $0.02-0.03 \mathrm{eV}$. This behavior of $\mathrm{RCH}\left(\mathrm{NH}_{2}\right) \mathrm{C}(=\mathrm{O}) \mathrm{NHCH}\left(\mathrm{R}^{\prime}\right) \mathrm{C}(=\mathrm{O}) \mathrm{X} \cdot \mathrm{H}^{+}$ions dif-

Table 2. FAB mass spectra of $\mathrm{H}-\mathrm{Gly}$-Leu-Gly-OH and $\mathrm{H}$-Leu-Gly-Gly-OH

\begin{tabular}{lcc}
\hline & \multicolumn{2}{c}{ Intensity as \% of base peak $(m / z)$} \\
\cline { 2 - 3 } Ion & H-Gly-Leu-Gly-OH & H-Leu-Gly-Gly-OH \\
\hline \hline $\mathrm{MH}^{+}$ & $46(246)$ & $42(246)$ \\
$\mathrm{B}_{2}$ & $18(171)$ & $9(171)$ \\
$\mathrm{A}_{2}$ & $52(143)$ & $3(143)$ \\
$\mathrm{Y}_{2}$ & $15(189)$ & $6(133)$ \\
$\mathrm{A}_{1}$ & & $100(86)$ \\
Other & $100(86)$ & \\
\hline
\end{tabular}




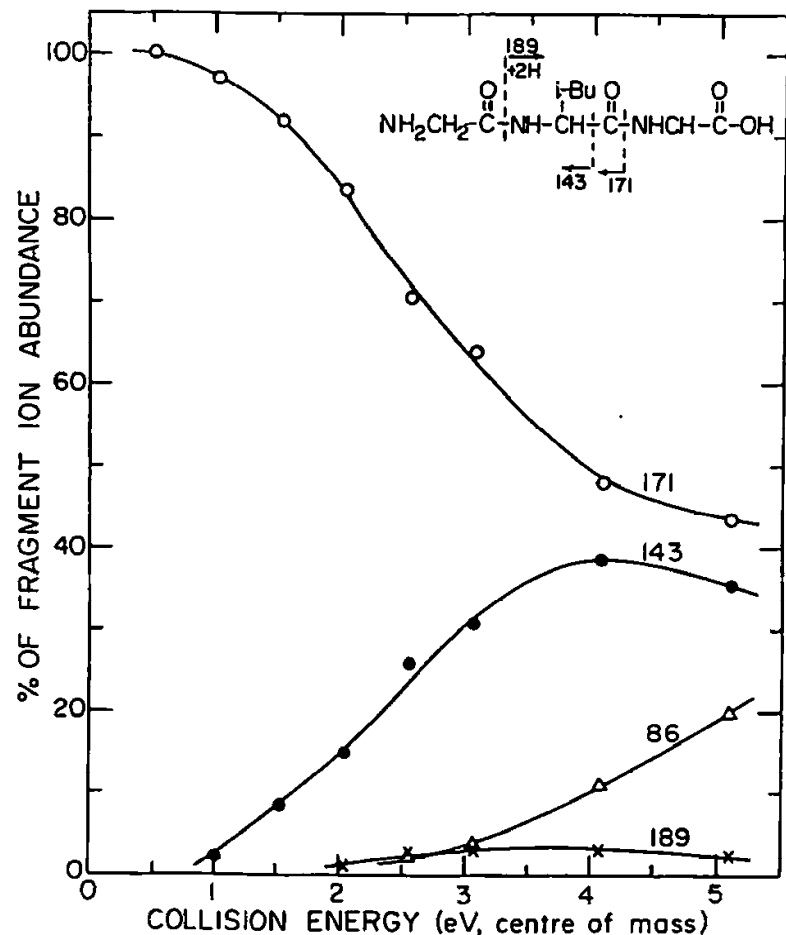

Figure 1. Breakdown graph for protonated H-Gly-Leu-Gly-OH

fers from that of $\mathrm{RCH}\left(\mathrm{NH}_{2}\right) \mathrm{C}(=\mathrm{O}) \mathrm{X} \cdot \mathrm{H}^{+}$ions, where the initial elimination of $\mathrm{HX}$ is followed by elimination of $\mathrm{CO}$ to give the immonium ion (reaction 3 ) in an overall reaction that yields a flat-topped metastable peak. Clearly the $B_{2}$ ion formed from the dipeptide derivatives has a much greater stability than the

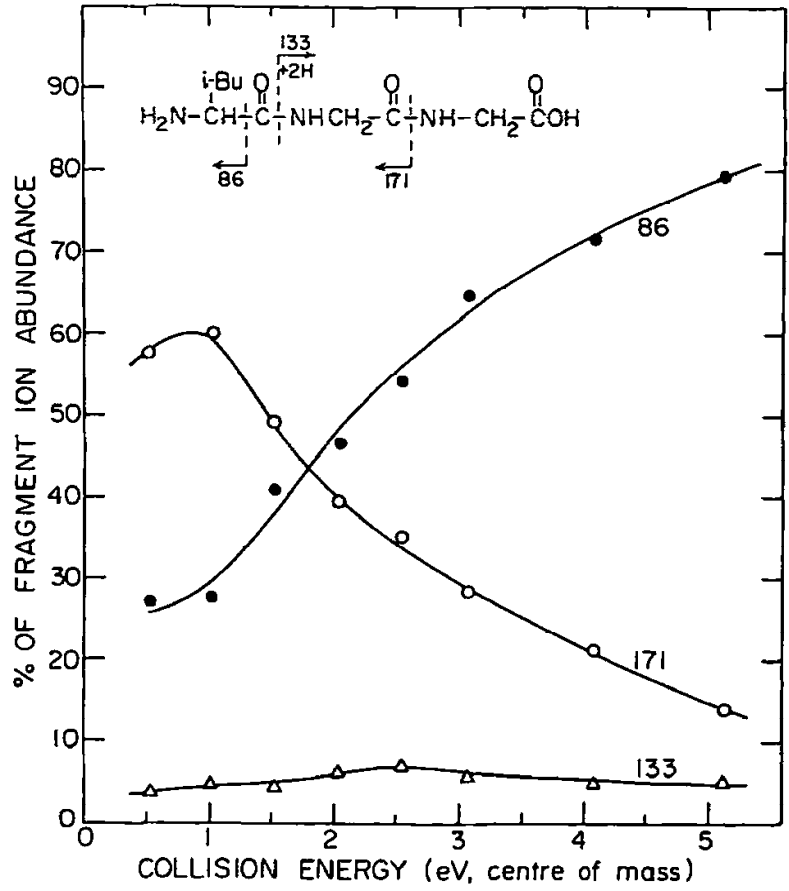

Figure 2. Breakdown graph for protonated H-Leu-Gly-Gly-OH.
Table 3. Kinetic energy releases in formation of $B_{2}$ ion

\begin{tabular}{|c|c|c|c|}
\hline $\mathrm{M}$ of $\mathrm{MH}^{+}$ & $\mathrm{HX}$ lost & $\begin{array}{c}m / z \\
B_{2} \text { ion }\end{array}$ & $T_{1 / 2}(\mathrm{eV})$ \\
\hline H-Gly-Leu-Gly-OH & $\mathrm{H}$-Gly-OH & 171 & 0.028 \\
\hline H-Gly-Leu-NH ${ }_{2}$ & $\mathrm{NH}_{3}$ & 171 & 0.027 \\
\hline H-Gly-Leu-OH & $\mathrm{H}_{2} \mathrm{O}$ & 171 & 0.029 \\
\hline $\mathrm{H}$-Ala-Ala-Gly-OH & $\mathrm{H}$-Gly-OH & 143 & 0.026 \\
\hline H-Ala-Ala-Ala-OMe & $\mathrm{H}$-Ala-OMe & 143 & 0.035 \\
\hline H-Ala-Ala-OMe & $\mathrm{CH}_{3} \mathrm{OH}$ & 143 & 0.022 \\
\hline H-Ala-Ala-Ala-OH & $\mathrm{H}$-Ala-OH & 143 & 0.025 \\
\hline H-Gly-Ala-Ala-OH & $\mathrm{H}$-Ala-OH & 129 & 0.031 \\
\hline $\mathrm{H}$-Gly-Ala-Gly-OH & $\mathrm{H}$-Gly-OH & 129 & 0.024 \\
\hline $\mathrm{H}$-Gly-Ala-NH ${ }_{2}$ & $\mathrm{NH}_{3}$ & 129 & 0.025 \\
\hline H-LeLL-Gly-Gly-OH & $\mathrm{H}$-Gly-OH & 171 & 0.033 \\
\hline H-Leu-Gly-NH ${ }_{2}$ & $\mathrm{NH}_{3}$ & 171 & 0.032 \\
\hline
\end{tabular}

acylium ion that would be formed from the amino acid derivatives.

In a number of cases the $B_{2}$ ions formed from the tripeptides and the dipeptide derivatives were of sufficient intensity in the $F A B$ mass spectrum that they could be mass-selected and their metastable ion fragmentation reactions studied by tandem mass spectrometry. In all cases metastable fragmentation by elimination of $\mathrm{CO}$ was observed and, as summarized in Table 4 , these metastable peaks were flat-topped with kinetic energy releases $\left(T_{1 / 2}\right)$ of $\sim 0.5 \mathrm{eV}$, except for the $\mathrm{B}_{2}$ ion derived from $\mathrm{H}$-Leu-Gly-X compounds, where a lower $T_{1 / 2}$ of $0.34-0.38 \mathrm{eV}$ was measured.

Thus, we have a situation where dipeptide derivatives $\mathrm{RCH}\left(\mathrm{NH}_{2}\right) \mathrm{C}(=\mathrm{O}) \mathrm{NHCH}\left(\mathrm{R}^{\prime}\right) \mathrm{C}(=\mathrm{O})-\mathrm{X}$, when protonated, fragment by loss of $H X$ to give $a B_{2}$ ion with a kinetic energy release in the metastable ion fragmentation that is quite small $\left(T_{1 / 2}=0.02-0.03 \mathrm{eV}\right)$. The resultant $B_{2}$ ions fragment, on the metastable ion time scale, by elimination of $\mathrm{CO}$ with a large kinetic release $\left(T_{1 / 2}\right.$ in the range $\left.0.3-0.5 \mathrm{eV}\right)$. This result suggests a potential energy profile for fragmentation of $B_{2}$ such as shown in Figure 3, where a stable ion (S) passes through a reacting configuration (RC) that is higher in energy than the final products $\mathrm{A}_{2}+\mathrm{CO}$. The relatively large kinetic energy release results because some of the energy released in the fragmentation step

Table 4. Kinetic energy releases in fragmentation reaction $\mathrm{B}_{2} \rightarrow \mathrm{A}_{2}+\mathrm{CO}$

\begin{tabular}{lcc}
\hline Peptide deriv. & Nominal $B_{2}$ ion & $T_{1 / 2}(\mathrm{eV})$ \\
\hline \hline H-Gly-Leu-Gly-OH & H-Gly-Leu & 0.49 \\
H-Gly-Leu-NH & H-Gly-Leu & 0.48 \\
H-Ala-Ala-Gly-OH & H-Ala-Ala & 0.57 \\
H-Ala-Ala-Ala-OMe & H-Ala-Ala & 0.54 \\
H-Ala-Ala-Ala-OH & H-Ala-Ala & 0.51 \\
H-Gly-Ala-Ala-OH & H-Gly-Ala & 0.50 \\
H-Gly-Ala-Gly-OH & H-Gly-Ala & 0.50 \\
H-Gly-Ala-NH & H-Gly-Ala & 0.53 \\
H-Leu-Gly-Gly-OH & H-Leu-Gly & 0.34 \\
H-Leu-Gly-NH & H-Leu-Gly & 0.38 \\
\hline
\end{tabular}




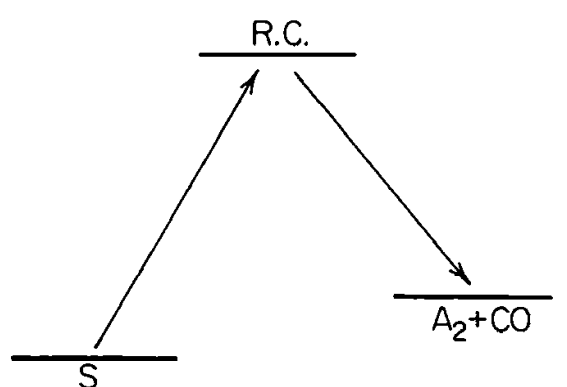

Figure 3. Potential energy profile for reaction that leads to a large kinetic energy release.

(the reverse activation energy) is partitioned into kinetic energy of the separating fragments $[13,14]$. The question then becomes what is the stable structure $S$ and what is the structure of the reacting configuration $\mathrm{RC}$ that leads to elimination of $\mathrm{CO}$ in an exothermic fragmentation reaction. The simplest postulate is that the reacting configuration is the acylium ion $\mathrm{RCH}\left(\mathrm{NH}_{2}\right) \mathrm{C}(=\mathrm{O}) \mathrm{NHCH}\left(\mathrm{R}^{\prime}\right) \mathrm{CO}^{+}$. As a candidate structure for the stable configuration $S$, we first considered the possibility that, on formation of $B_{2}$, cyclization occurred through interaction with the $\mathrm{N}$-terminus amino group as indicated in Scheme III for the H-LeuGly-X and H-Gly-Leu-X systems. This possibility can be tested experimentally because the cyclic intermediate can be prepared, as indicated in Scheme III, by protonation of the corresponding diketopiperazine: cyclo-Leu-Gly. (It may well be assumed that the added proton is mobile and that the same cyclic intermediate or mixture of intermediates is formed in all cases.)

Figure 4 compares the metastable ion mass spectrum for the $m / z 171\left(\mathrm{~B}_{2}\right)$ ion derived from H-GlyLeu-Gly-OH and from $\mathrm{H}-\mathrm{Gly}-\mathrm{Leu}-\mathrm{NH}_{2}$ with the metastable ion mass spectrum for the $m / z 171$ ion derived by protonation of cyclo-Leu-Gly. Figure 5 shows the same comparison for the $m / z 171\left(B_{2}\right)$ ion derived from $\mathrm{H}$-Leu-Gly-Gly-OH and from H-LeuGly- $\mathrm{NH}_{2}$. All spectra refer to decomposition reactions

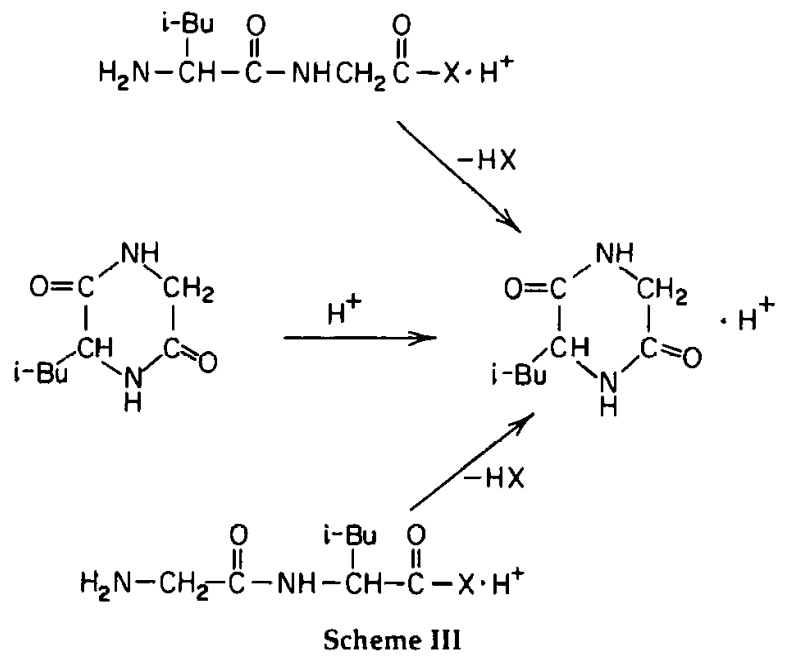

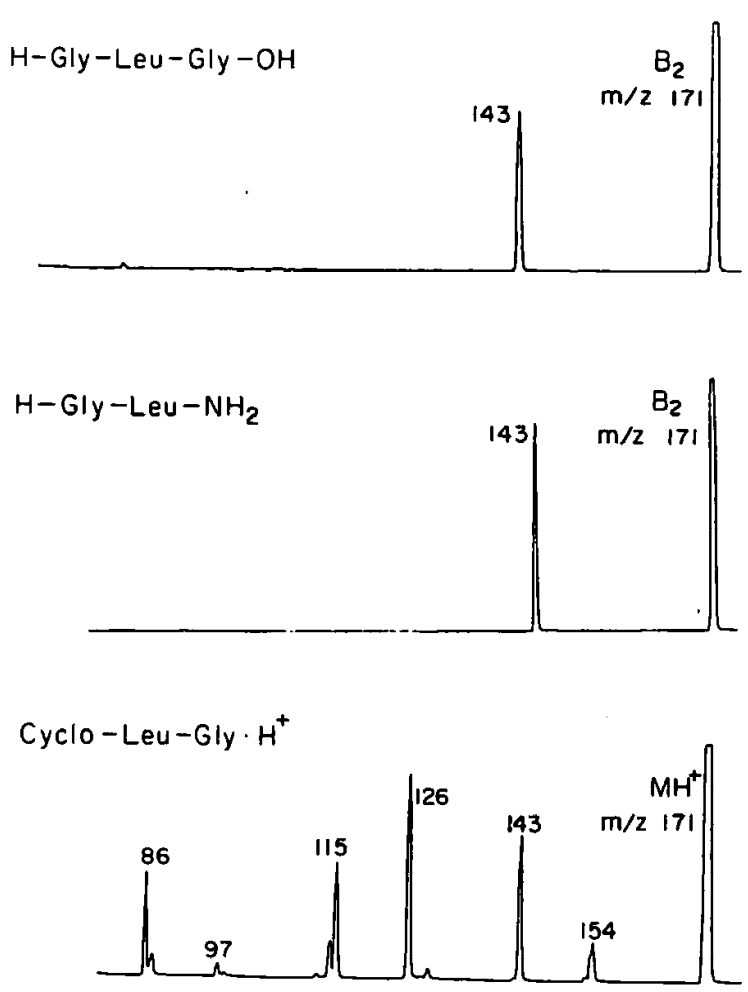

Figure 4. Comparison of metastable ion mass spectra (quadrupole cell) of $\mathrm{B}_{2}$ ion from H-Gly-Leu-X. $\mathrm{H}^{+}$and protonated cyclo-Leu-Gly.

that occur in the quadrupole cell in the absence of collision gas. Clearly, the metastable ion mass spectra for the $B_{2}$ ions derived from the acyclic peptides are significantly different from the spectrum derived from the protonated cyclic dipeptide or diketopiperazine. Thus, we conclude that cyclization to a protonated diketopiperazine has not occurred on formation of the $B_{2}$ ion. This conclusion was reached previously by Wesdemiotis and co-workers [24] from a comparison of the high energy CID mass spectrum of the $B_{2}$ ion derived from protonated trialanine with the CID mass spectrum of the $\mathrm{MH}^{+}$ion of cyclo-Ala-Ala (3,6dimethyl-2,4-piperazinedione).

In addition to the $\mathrm{N}$-terminus amino group, the compounds we have examined contain a remote carbonyl group associated with the $\mathrm{N}$-terminus amino acid and it is possible that stabilization of the incipient $\mathrm{B}_{2}$ ion occurs by interaction with this carbonyl group. (Such an interaction has been suggested by Wesdemiotis and co-workers [24] and by Hunt and co-workers [25]. Tang et al. [26] also have proposed that $B$ ions can have more than one structure with the "cyclic" form being more stable, although the cyclic structure was not clearly identified.) To probe for such an interaction experimentally we have eliminated the terminal amino group while retaining the carbonyl group by examination of the fragmentation reactions of protonated $\mathrm{N}$ acetyl peptide and amino acid derivatives. Table 5 presents the FAB mass spectra of two $N$-acetyl dipeptides: Ac-Leu-Gly-OH and Ac-Ala-Ala-OH. In both 


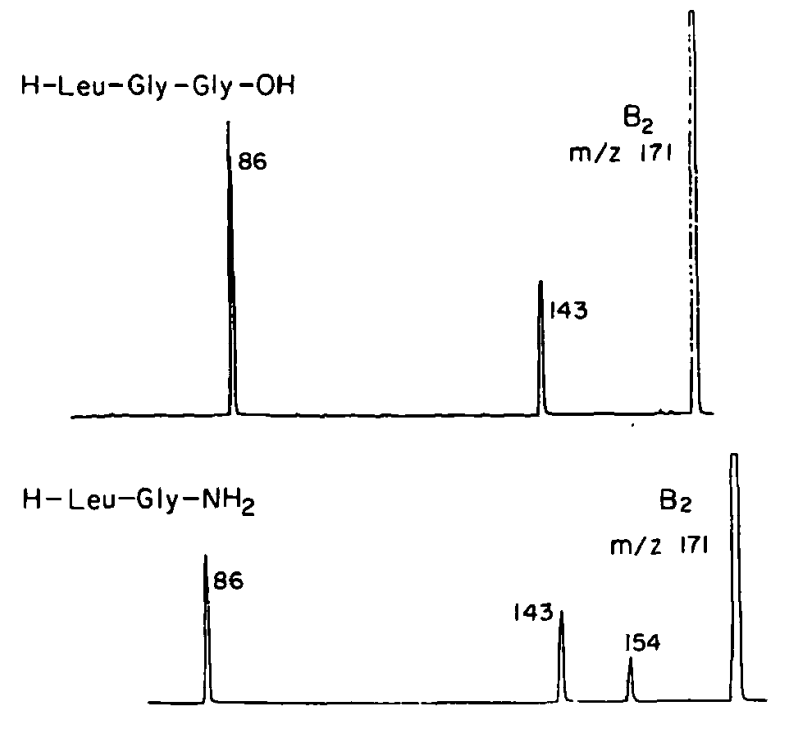

$$
\text { Cyclo-Leu-Gly } \cdot \mathrm{H}^{+}
$$

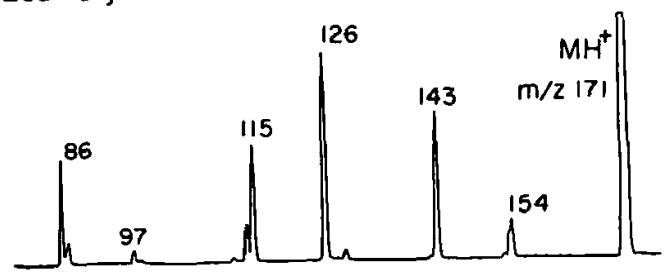

Figure 5. Comparison of metastable ion mass spectra (quadrupole cell) of $\mathrm{B}_{2}$ ion from $\mathrm{H}$-Leu-Gly-X. $\mathrm{H}^{+}$and protonated cyclo-Leu-Gly.

cases significant ion signals are observed that correspond to loss of the C-terminus amino acid as a neutral to give the $\mathrm{B}$ ion with the nominal structure $\mathrm{CH}_{3} \mathrm{C}(=\mathrm{O}) \mathrm{NHCH}(\mathrm{R}) \mathrm{CO}^{+}(\mathrm{m} / \mathrm{z} 156$ for Ac-Leu-Gly$\mathrm{OH}$ and $m / z 114$ for Ac-Ala-Ala-OH). Furthermore, as Figures 6 and 7 show, CID of the $\mathrm{MH}^{+}$ion yields the same ion as the dominant low energy fragmentation channel for Ac-Leu-Gly-OH, whereas protonated AcAla-Ala-OH shows a more complicated breakdown graph that includes formation of the B ion as a significant fragment.

A variety of protonated species of the type $\mathrm{CH}_{3} \mathrm{C}(=\mathrm{O}) \mathrm{NHCH}(\mathrm{R}) \mathrm{C}(=\mathrm{O}) \mathrm{X} \cdot \mathrm{H}^{+}$were studied, where $\mathrm{X}$ was an amino acid, $\mathrm{NH}_{2}, \mathrm{OH}$, or $\mathrm{OCH}_{3}$. In all cases metastable peaks were observed that corre-

Table 5. FAB mass spectra of Ac-Leu-Gly-OH and Ac-Ala-Ala-OH

\begin{tabular}{lcc}
\hline & \multicolumn{2}{c}{ Intensity as \% base peak $(\mathrm{m} / \mathrm{z})$} \\
\cline { 2 - 3 } Ion & Ac-Leu-Gly-OH & Ac-Ala-Ala-OH \\
\hline \hline $\mathrm{MH}^{+}$ & $45(231)$ & $100(203)$ \\
$\mathrm{B}$ & $45(156)$ & $80(114)$ \\
$\mathrm{A}$ & $51(128)$ & $52(86)$ \\
$\mathrm{Y}$ & & $39(90)$ \\
$\mathrm{A}-\mathrm{CH}_{2} \mathrm{CO}$ & $100(86)$ & $10(161)$ \\
$\mathrm{MH}^{+}-\mathrm{CH}_{2} \mathrm{CO}$ & & \\
\hline
\end{tabular}

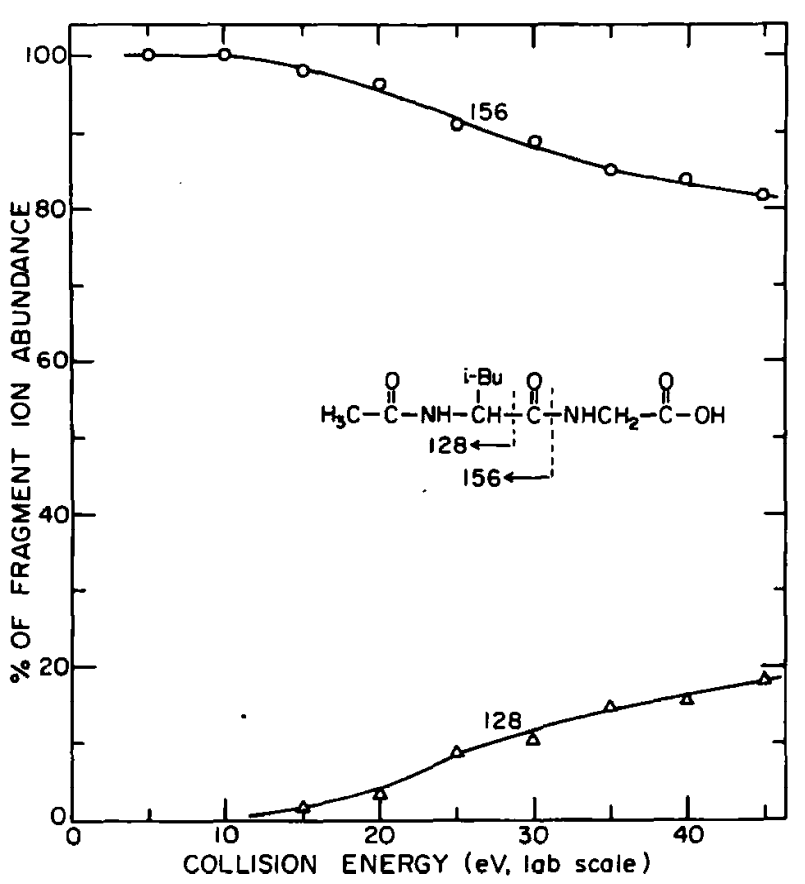

Figure 6. Breakdown graph for protonated Ac-Leu-Gly-OH.

sponded to elimination of $\mathrm{HX}$ and formation of stable B-type ions. As indicated by the data in Table 6, these metastable peaks were Gaussian in shape with low kinetic releases $\left(T_{1 / 2}\right.$ in the range $\left.0.02-0.04 \mathrm{eV}\right)$. In a number of cases the FAB mass spectra showed sufficient intensity of these B-type ions that they could be mass-selected and their metastable ion decomposition reactions could be studied. In all cases unimolecular elimination of $\mathrm{CO}$ was observed to give flat-topped metastable peaks with kinetic energy releases $\left(T_{1 / 2}\right)$ in the range $0.44-0.53 \mathrm{eV}$ (Table 7).

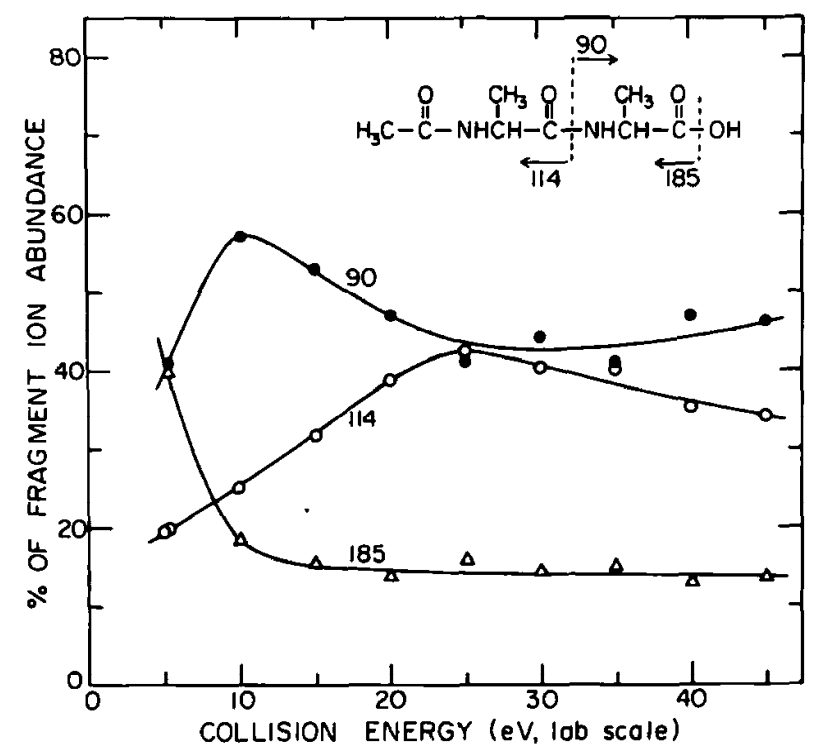

Figure 7. Breakdown graph for protonated Ac-Ala-Ala-OH. 
Table 6. Kinetic energy releases in fragmentation reaction $\mathrm{Ac}-\mathrm{NHCH}(\mathrm{R}) \mathrm{C}(=\mathrm{O}) \mathrm{X} \cdot \mathrm{H}^{+} \rightarrow \mathrm{B}$ ion $+\mathrm{HX}$

\begin{tabular}{|c|c|c|}
\hline Compound & $\mathrm{HX}$ lost & $T_{1 / 2}(\mathrm{eV})$ \\
\hline Ac-Leu-Gly-OH & $\mathrm{H}-\mathrm{Gly}-\mathrm{OH}$ & 0.023 \\
\hline Ac-Leu-OH & $\mathrm{H}_{2} \mathrm{O}$ & 0.034 \\
\hline Ac-Leu-NH ${ }_{2}$ & $\mathrm{NH}_{3}$ & 0.032 \\
\hline Ac-Leu-OMe & $\mathrm{MeOH}$ & 0.032 \\
\hline Ac-Ala-Ala-OH & $\mathrm{H}$-Ala-OH & 0.029 \\
\hline Ac-Ala-OH & $\mathrm{H}_{2} \mathrm{O}$ & 0.034 \\
\hline Ac-Ala- $\mathrm{NH}_{2}$ & $\mathrm{NH}_{3}$ & 0.019 \\
\hline Ac-Ala-OMe & $\mathrm{MeOH}$ & 0.025 \\
\hline Ac-Pro-OMe & $\mathrm{MeOH}$ & 0.031 \\
\hline Ac-Pro- $\mathrm{NH}_{2}$ & $\mathrm{NH}_{3}$ & 0.031 \\
\hline
\end{tabular}

Thus, we find that the fragmentation behavior of the protonated species

$$
\mathrm{CH}_{3} \mathrm{C}(=\mathrm{O}) \mathrm{NHCH}(\mathrm{R}) \mathrm{C}(=\mathrm{O}) \mathrm{X} \cdot \mathrm{H}^{+}
$$

closely parallels the fragmentation of the protonated species

$$
\mathrm{H}_{2} \mathrm{NCH}\left(\mathrm{R}^{\prime}\right) \mathrm{C}(=\mathrm{O}) \mathrm{NHCH}(\mathrm{R}) \mathrm{C}(=\mathrm{O}) \mathrm{X} \cdot \mathrm{H}^{+} .
$$

In both cases $\mathrm{HX}$ is eliminated in reactions that result in Gaussian metastable peaks with low kinetic energy releases to form a stable B-type ion. Again, in both cases, the $B$ ion fragments, at least in part, by elimination of $\mathrm{CO}$, reactions that are accompanied by a large kinetic release $\left(T_{1 / 2}=0.3-0.5 \mathrm{eV}\right)$. This implies that, for the $B$ ion of nominal structure $\left.\mathrm{CH}_{3} \mathrm{Cl}=\mathrm{O}\right) \mathrm{NHCH}(\mathrm{R}) \mathrm{CO}^{+}$, the reaction that results in elimination of $\mathrm{CO}$ follows a potential energy profile such as shown in Figure 3. Again, the simplest rationalization is that the reacting configuration (RC) is the acyclic acylium ion. We propose that the stable configuration (S) of the $B$ ion results from interaction of the developing charge as the ion is formed with the $\mathrm{N}$-terminus carbonyl group to give the structure $\mathrm{d}$ of Scheme IV for the acyl derivative. By analogy, the structure for the dipeptide derivatives is shown as structure e.

These structures are protonated oxazolones. Oxazolones are known to be formed by dehydration of $\mathrm{N}$-acyl amino acids [27]; in essence, structure $d$ is that

Table 7. Kinetic energy releases in loss of $\mathrm{CO}$ from

\begin{tabular}{|c|c|c|}
\hline Compound & Nominal B ion & $T_{1 / 2}(e V)$ \\
\hline Ac-Leu-Gly-OH & Ac-Leu & 0.48 \\
\hline Ac-Leu-OH & Ac-Leu & 0.44 \\
\hline Ac-Leu-NH ${ }_{2}$ & Ac-Leu & 0.45 \\
\hline Ac-Leu-OMe & Ac-Leu & 0.51 \\
\hline Ac-Ala-Ala-OH & Ac-Ala & 0.48 \\
\hline Ac-Ala-OH & Ac-Ala & 0.48 \\
\hline Ac-Ala- $\mathrm{NH}_{2}$ & Ac-Ala & 0.50 \\
\hline Ac-Pro-OMe & Ac-Pro & 0.53 \\
\hline Ac-Pro-NH ${ }_{2}$ & Ac-Pro & 0.51 \\
\hline
\end{tabular}
$\mathrm{N}$-acetyl-B ions<smiles>[R]C1N[C+](C)OC1=O</smiles><smiles>[R]C1N[C-](C([R])N)OC1=O</smiles>

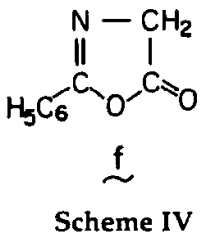

expected by acid-catalyzed dehydration of an $\mathrm{N}$-acetyl amino acid. To provide some experimental support for our hypothesis we have protonated 2-phenyl-5-oxazolone ( $f$, Scheme IV) by FAB and have compared the fragmentation reactions of this protonated species with the fragmentation reactions of the $\mathrm{B}$ ion [nominally $\mathrm{C}_{6} \mathrm{H}_{5} \mathrm{C}(=\mathrm{O}) \mathrm{NHCH}_{2} \mathrm{CO}^{+}$] observed in the $\mathrm{FAB}$ mass spectrum of $\mathrm{C}_{6} \mathrm{H}_{5} \mathrm{C}(=\mathrm{O})$ Gly-Gly-OH; the $\mathrm{B}$ ion arises by loss of neutral glycine from the $\mathrm{MH}^{+}$ion. Both ions $(m / z 162)$ fragment unimolecularly by elimination of $\mathrm{CO}$ only. In both cases flat-topped metastable peaks were observed in the MIKE spectra with kinetic energy releases $\left(T_{1 / 2}\right)$ of $0.34 \mathrm{eV}$ for the protonated oxazolone and $0.31 \mathrm{eV}$ for the $\mathrm{B}$ ion. The low energy (45-eV) CID mass spectra of the protonated oxazolone and the $\mathrm{B}$ ion derived from the $\mathrm{N}$-benzoyl peptide are compared in Figure 8. Although the CID spectra are simple, the close similarity of the spectra, coupled with the agreement of the $T_{1 / 2}$ values for metastable loss of $\mathrm{CO}$, provide strong evidence that the two ions have the same structure. This agreement provides strong support for the representation of the stable forms of the $B$ ions from the $\mathrm{N}$-acyl peptides and the dipeptide
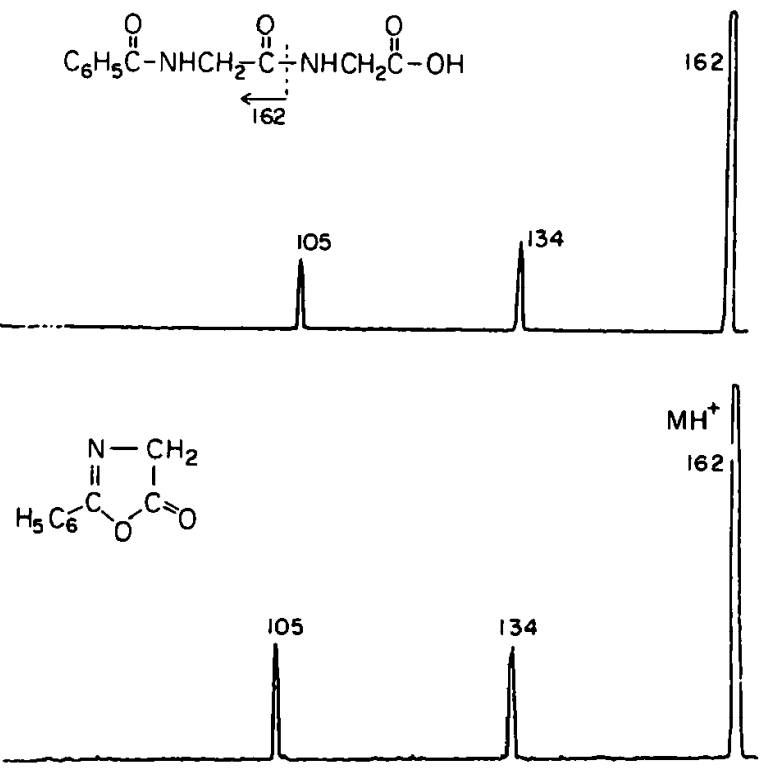

Figure 8. CID spectra (45 eV) of $B$ ion derived from $N$-benzoylGly-Gly-OH and protonated 2-phenyl-5-oxazolone. 
derivatives as structures $\mathbf{d}$ and $\mathbf{e}$. To provide further evidence we have undertaken $a b$ initio calculations, described in the next section, on the simplest possible $\mathrm{B}$ ion, nominally $\mathrm{HC}(=\mathrm{O}) \mathrm{NHCH}_{2} \mathrm{CO}^{+}$, and its fragmentation products.

\section{Theoretical Calculations}

The ab initio calculations were carried out by using the GAUSSIAN 92 series of programs [28] that employed restricted Hartree-Fock (RHF) formalism. Fully optimized geometries were calculated initially at the 3-21G split valence basis set [29] level of theory. These geometrical parameters were used subsequently for input to calculations of the fully relaxed geometries, total energies, and harmonic frequencies at the $\mathrm{HF} / 6-31 \mathrm{G}^{* *}$ level of theory. Figures 9,10 , and 11 show the structures of the species for which calculations were performed, whereas Table 8 lists the total energies calculated at the $3-21 \mathrm{G}$ and $6-31 \mathrm{G}^{* *}$ levels of theory.

With full geometry optimization for the nominal ion $\mathrm{HC}(=\mathrm{O}) \mathrm{NHCH}_{2} \mathrm{CO}^{+}$, the global energy minimum found was for the cyclic structure g. ${ }^{*}$ To obtain an energy for the acyclic structure $\mathbf{h}$ it was necessary to hold the torsional angle $\angle C_{1} C_{3}-N_{2} C_{5}$ at $180^{\circ}$. Under these conditions one imaginary frequency resulted, which indicated that the structure corresponded to a saddle point or transition state not a stable structure on the potential energy hypersurface.

The calculations fully support the hypothesis that

* Calculations also were performed at the 3-21C level for the $\mathrm{B}_{2}$ ion, nominally $\left.\mathrm{H}_{2} \mathrm{NCH}_{2} \mathrm{Cr}=\mathrm{O}\right) \mathrm{NHCH}_{2} \mathrm{CO}^{*}$. The global energy minimum was found to correspond to the protonated oxazolone (e, Scheme IV: $R=R^{\prime}=H$ ), which indicates that the presence of the terminal amino group does not alter the nature of the cyclization reaction that occurs.

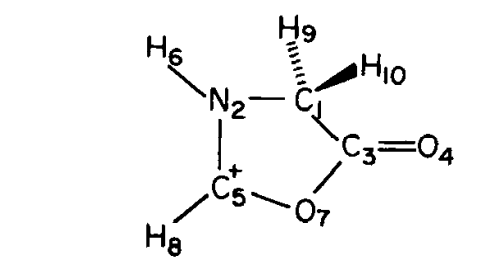

\begin{tabular}{l|l}
\multicolumn{2}{l}{ Geometrical parameters } \\
$r_{12}=1.4621$ & $\mathrm{~N}_{2} \mathrm{C}_{1} \mathrm{C}_{3}=100.4628$ \\
$r_{13}=1.5167$ & $\mathrm{C}_{1} \mathrm{C}_{3} \mathrm{O}_{4}=132.8743$ \\
$r_{34}=1.1505$ & $\mathrm{C}_{5} \mathrm{~N}_{2} \mathrm{C}_{1}=110.6113$ \\
$r_{25}=1.2821$ & $\mathrm{H}_{5} \mathrm{~N}_{2} \mathrm{C}_{6}=123.9806$ \\
$r_{62}=1.0004$ & $\mathrm{O}_{7} \mathrm{C}_{5} \mathrm{~N}_{2}=114.6771$ \\
$r_{57}=1.2819$ & $\mathrm{H}_{6} \mathrm{C}_{5} \mathrm{~N}_{2}=125.6034$ \\
$r_{73}=1.4284$ & $\mathrm{Alf}_{\mathrm{f}}=111.7865$ \\
$r_{85}=1.0748$ & $\mathrm{C}_{3} \mathrm{C}_{1} \mathrm{~N}_{2} \mathrm{C}_{5}=0.0^{\circ}$ \\
$r_{91}=1.0819$ & $\mathrm{O}_{4} \mathrm{C}_{3} \mathrm{C}_{1} \mathrm{~N}_{2}=180.0^{\circ}$ \\
$r_{101}=1.0819$ &
\end{tabular}

Figure 9. Molecular structure of protonated oxazolone g.<smiles>C[13C](=O)N(C)C(C)(C)C=O</smiles>

\section{Geometrical parameters}

\begin{tabular}{l|l}
$r_{21}=1.4329$ & $C_{3} C_{1} N_{2}=110.5712$ \\
$r_{13}=1.4844$ & $O_{4} C_{3} C_{1}=178.317$ \\
$r_{34}=1.0944$ & $C_{5} N_{2} C_{1}=114.2553$ \\
$r_{52}=1.3802$ & $H_{6} N_{2} C_{5}=121.8629$ \\
$r_{62}=0.9952$ & $O_{7} C_{5} N_{2}=120.3467$ \\
$r_{57}=1.1841$ & $H_{8} C_{5} N_{2}=114.0247$ \\
$r_{85}=1.0854$ & $A 1 f a=113.5587$ \\
$r_{91}=1.0894$ & $O_{4} C_{3} C_{1} N_{1}=180.0^{\circ}$ \\
$r_{101}=1.0894$. & $O_{5} N_{2} C_{1} C_{3}=180.0^{\circ}$
\end{tabular}

Figure 10. Molecular structure of acyclic acylium ion $h$.

$\mathrm{B}_{2}$ ions, on formation, undergo cyclization and fragment by loss of $\mathrm{CO}$, in accordance with the mechanism shown in Scheme V. Figure 12 schematically shows a cross section of the potential energy hypersurface as the potential energy profile for this fragmentation reaction as derived from the calculated energies. The acyclic acylium ion is calculated to be $1.49 \mathrm{eV}$ higher in energy than the cyclic protonated oxazolone and $0.88 \mathrm{eV}$ higher in energy than the final fragmentation products $\mathrm{HC}(=\mathrm{O}) \mathrm{N}^{+} \mathrm{H}=\mathrm{CH}_{2}+\mathrm{CO}$. This latter energy difference is consistent with the substantial kinetic energy releases $\left(T_{1 / 2}=0.3-0.5 \mathrm{eV}\right)$ we have measured for unimolecular elimination of $\mathrm{CO}$ from the $\mathrm{B}$ ions studied.

\section{Conclusions}

The essential conclusion of the present study is that the $B_{2}$ ion observed as a stable species in peptide mass

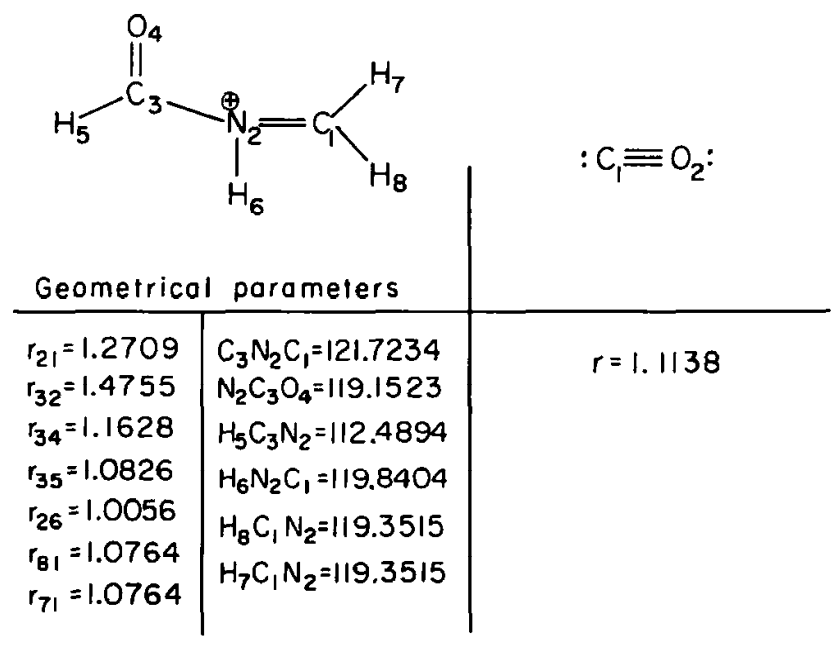

Figure 11. Molecular structure of fragmentation products. 
Table 8. Total calculated energies

\begin{tabular}{lll}
\hline & \multicolumn{2}{c}{ Energy (Hartree) } \\
\cline { 2 - 3 } Species $^{2}$ & HF/3-21G & HF/6-31G** \\
\hline \hline $\mathbf{g}$ & $-\mathbf{3 1 8 . 0 6 4 7 6 9}$ & -319.869665 \\
$\mathbf{h}$ & -318.004654 & -319.814845 \\
$\mathbf{i}$ & -205.940195 & -207.109059 \\
$\mathbf{j}$ & -112.093299 & -112.737877 \\
\hline
\end{tabular}

${ }^{\circ} \mathrm{g}=$ protonated oxazolone (cf. Figure 9 ); $\mathbf{h}=$ acyclic acylium ion (cf. Figure 10); $\mathrm{i}=$ immonium ion (cf. Figure 11 ); $\mathrm{j}=$ carbon monoxide (cf. Figure 11).

spectra is not an acyclic acylium ion but has cyclized by interaction with the $\mathrm{N}$-terminus carbonyl function to form a protonated substituted oxazolone. This protonated oxazolone fragments by ring opening to an acyclic acylium ion that exothermically eliminates $\mathrm{CO}$. A considerable part of this exothermicity is released as kinetic energy of the separating fragments and leads to flat-topped metastable ion peaks.

We believe that the larger stable $B$ ions, $B_{3}, B_{4}$, and so forth, also have cyclic structures although it is not clear whether cyclization has occurred by interaction

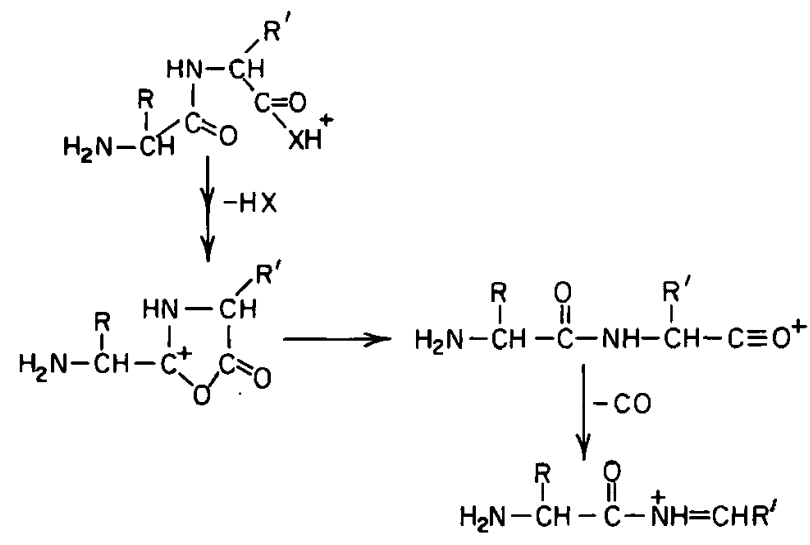

Scheme V

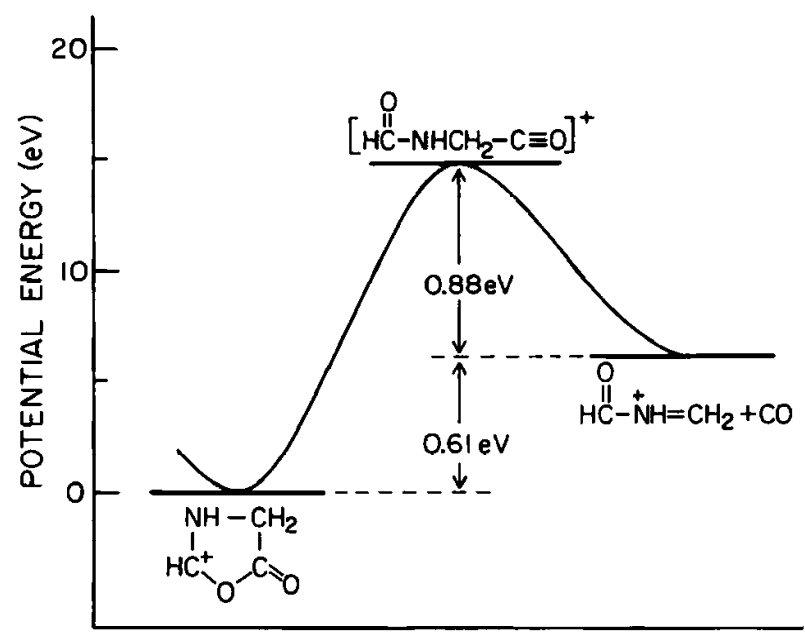

REACTION COORDINATE

Figure 12. Calculated potential energy profile for fragmentation of $\mathrm{B}$ ion. with the next adjacent carbonyl function or with a more remote carbonyl function. This question is under study in our laboratory.

\section{Acknowledgments}

The authors are indebted to the Natural Sciences and Engineering Research Council (Canada) for financial support and to VG Analytical/Fisons Instruments, Inc. for the loan of the FAB source and fast-atom gun.

\section{References}

1. Weinkam, R. J.; Gal, J. Org. Mass Spectrom. 1976, 11, 188.

2. Ichikawa, H.; Harrison, A. G. Org. Mass Spectrom. 1978, 13, 389.

3. Middlemiss, N. E.; Harrison, A. G. Can. J. Chem. 1979, 57 , 2827.

4. Harrison, A. G.; Kallury, R. K. M. R. Org. Mass Spectrom. 1980, 15, 277.

5. Weinkam, R. J. J. Am. Chem. Soc. 1974, 96, 1032.

6. Tsang, C. W.; Harrison, A. G. J. Chem. Soc. Perkin Trans. 2 $1975,1718$.

7. LeClerq, P. M., Desiderio, D. M. Org. Mass Spectrom. 1973, 7, 515.

8. Tsang, C. W.; Harrison, A. G. J. An. Chem. Soc. 1976, 98, 1301.

9. Bouchoux, G.; Bourcier, S.; Hoppilliard, Y.; Mauriac, C. Org. Mass Spectrom. 1993, 28, 1064.

10. Kulik, W.; Heerma, W. Biomed. Environ. Mass Spectron. 1988, $15,419$.

11. Bouchonnet, S.; Denhez, J. P.; Hoppilliard, Y.; Mauriac, C. Anal. Chent. 1992, 64, 743.

12. Benoit, F. M.; Harrison, A. G. J. Am. Chem. Soc. 1977, 98, 3980.

13. Cooks, R. G.; Beynon, J. H.; Caprioli, R. M.; Lester, G. R. Metastable lons; Elsevier: New York, 1973.

14. Holmes, J. L.; Terlouw, J. K. Org. Mass Spectrom. 1980, 15. 383.

15. Roepstorff, P.; Fohlman, J. Biomed. Mass Spectrom. 1984, 11. 601.

16. Hunt, D. F.; Yates, J. R., Ill; Shabanowitz, J.; Winston, S.; Hauer, C. R. Proc. Natl. Acad. Sci. USA 1986, 83, 6233.

17. Biemann, K.; Martin, S. Mass Spectrom. Rev. 1987, 6, 75.

18. Biemann, K. Biomed. Environ. Mass Spectrom. 1988, 16, 99.

19. Biemann, K. In Mass Spectrometry Methods in Enzymology, Vol. 193; McCloskey, J. A., Ed.; Academic Press: San Diego, CA, 1990; Chaps. 18, 25.

20. Biemann, K. In Biological Mass Spectronetry Present and Future; Matsuo, T.; Caprioli, R. M.; Gross, M. L.; Seyama, Y., Eds.; Wiley: New York, 1993.

21. Tang, X.-J.; Boyd, R. K. Rapid Commun. Mass Specirom. 1992, 6,651 .

22. Harrison, A. G.; Mercer, R. S.; Reiner, E. J.; Young, A. B.; Boyd, R. K.; March, R. E.; Porter, C. J. Int. J. Mass Spectrom. Ion Processes 1986, 76, 13

23. (a) Strukov, I. T. Zh. Obshch. Khim. 1959, 29, 2359 (Chem. Abstracts 1960, 54, 9889); (b) Grahl-Nielsen, O.; Solheim, E. Anal. Chem. 1975, 47, 333.

24. Cordero, M. M.; Houser, J. J.; Wesdemiotis, C. Anal. Chem. 1993, 65, 1594.

25. Arnott, D.; Kottmeir, D.; Yates, N.; Shabanowitz, J.; Hunt, D. F. Proceedings of the 42nd ASMS Conference on Mass Spectrometry; Chicago, June, 1994; $\mathrm{P} 470$.

26. Tang, X.-J.; Thibault, P.; Boyd, R. K. Annl. Chem. 1993, 65. 2824. 
27. Rao, R. S.; Filler, R. In Oxazoles. The Chemistry of Heterocyclic Compounds, Vol. 45; Turchi, I. J., Ed.; Wiley: New York, 1986; Chap. 4.

28. Frisch, M. J.; Trucks, G. W.; Head-Gordon, M.; Gill, P. M. W.; Wong, M. W.; Foresman, J. B.; Johnson, B. G.; Schlegel, H. B.; Robb, M. A.; Replogle, E. S.; Gomperts, R.; Andres, J. A.;
Raghavachari, K.; Binkley, J. S.; Gonzalez, C.; Martin, R. L.; Fox, D. J.; Defrees, D. J.; Baker, J.; Stewart, J. J. P.; Pople, J. A. Gaussian 92; Gaussian: Pittsburgh, PA, 1992.

29. Binkley, J. S.; Pople, J. A.; Hehre, W. J. J. Am. Chrm. Soc. 1980, $102,939$. 